\title{
Corrigendum to: Rhythmicity and cross-modal temporal Cues facilitate Detection [Neuropsychologia 63 (2014) 43-50]
}

Citation for published version (APA):

ten Oever, S., Schroeder, C. E., Poeppel, D., van Atteveldt, N., \& Zion-Golumbic, E. (2016). Corrigendum to: Rhythmicity and cross-modal temporal Cues facilitate Detection [Neuropsychologia 63 (2014) 43-50]. Neuropsychologia, 80, 221-221. https://doi.org/10.1016/j.neuropsychologia.2015.10.011

Document status and date:

Published: 08/01/2016

DOI:

10.1016/j.neuropsychologia.2015.10.011

Document Version:

Publisher's PDF, also known as Version of record

\section{Please check the document version of this publication:}

- A submitted manuscript is the version of the article upon submission and before peer-review. There can be important differences between the submitted version and the official published version of record.

People interested in the research are advised to contact the author for the final version of the publication, or visit the DOI to the publisher's website.

- The final author version and the galley proof are versions of the publication after peer review.

- The final published version features the final layout of the paper including the volume, issue and page numbers.

Link to publication

\footnotetext{
General rights rights.

- You may freely distribute the URL identifying the publication in the public portal. please follow below link for the End User Agreement:

www.umlib.nl/taverne-license

Take down policy

If you believe that this document breaches copyright please contact us at:

repository@maastrichtuniversity.nl

providing details and we will investigate your claim.
}

Copyright and moral rights for the publications made accessible in the public portal are retained by the authors and/or other copyright owners and it is a condition of accessing publications that users recognise and abide by the legal requirements associated with these

- Users may download and print one copy of any publication from the public portal for the purpose of private study or research.

- You may not further distribute the material or use it for any profit-making activity or commercial gain

If the publication is distributed under the terms of Article $25 \mathrm{fa}$ of the Dutch Copyright Act, indicated by the "Taverne" license above, 


\title{
Corrigendum
}

\section{Corrigendum to: Rhythmicity and cross-modal temporal Cues facilitate Detection [Neuropsychologia 63 (2014) 43-50]}

\author{
Sanne ten Oever ${ }^{\mathrm{a}}$, Charles E. Schroeder ${ }^{\mathrm{b}, \mathrm{c}}$, David Poeppel ${ }^{\mathrm{d}}$, Nienke van Atteveldt ${ }^{\mathrm{a}, \mathrm{e}}$, \\ Elana Zion-Golumbic ${ }^{\mathrm{b}, \mathrm{c}, \mathrm{f}}$ \\ a Faculty of Psychology and Neuroscience, Maastricht University, 6200 MD Maastricht, The Netherlands \\ ${ }^{\mathrm{b}}$ Departments of Psychiatry and Neurology, Columbia University Medical Center, New York, NY 10032, USA \\ ${ }^{\mathrm{c}}$ The Nathan Kline Institute for Psychiatric Research, Orangeburg, NY 10962, USA \\ d Department of Psychology, New York University, New York, NY 10003, USA \\ e Department of Educational Neuroscience, Faculty of Psychology and Education and Institute Learn, VU University Amsterdam, The Netherlands \\ ${ }^{\mathrm{f}}$ Gonda Brain Research Center, Bar Ilan University, Ramat Gan, Israel
}

The authors regret not having included all the funding sources in the original article and apologize for any inconvenience caused. Below are the new acknowledgments.

\section{Acknowledgments}

This study was supported by Grants from the Dutch Organization for Scientific Research [NWO; Grant numbers 406-11-068 (to StO) and 451-07-020 (to NvA)], the National Institutes of Health [NIH; Grant numbers R01-DC0566 (to DP), R01-DC011490 (to CES), MH103814 (to CES), and F32-MH093061 (to EZG)], and European Community's Seventh Framework Programme [FP/ 2007-2013; Grant number 22187 (to NvA)].

DOI of original article: 10.1016/j.neuropsychologia.2014.08.008. 